\title{
INTENSIVE PASTURE UTILIZATION AND ANIMAL PRODUCTION IN NEW ZEALAND
}

\author{
A. G: Самpвell \\ Ruakura Agricultural Research Centre, Hamilton
}

\section{INTRODUCTION}

Commercial, non-pedigree, livestock farmers in New Zealand find their economic future limited by the volume of animal products which they can sell from their farms. Inexpensive fodders and grains are not available in sufficient quantity to permit anything approaching the "feedlot" farming of other countries. Increased volume of output must, therefore, come substantially from those crops the farm can grow, and grow most efficiently. Climate, topography and experience currently dictate that this is the grass crop. The development of new skills and new technology may change this on those limited areas of New Zealand on which topography permits arable farming, but any widespread modification to the traditional pattern is a long way off.

Increasing the volume of output then depends on increasing pasture production and improving the utilization of the pasture grown. As early as 1929, Fawcett observed an association between stocking rate (i.e., the number of stock carried per acre of pasture) and per-acre yield of animal product. "Other things being equal", he said, "the number of cows carried per given area determines the limits of butterfat products". A nation-wide survey of 19,307 dairy farms by the Government Statistician in 1936 (N.Z. Official Yearbook, 1938) showed a similar association, and early surveys such as those of the Waipa and Whangarei counties appeared to confirm it (Mitchell, 1950; Dick, 1950). Later, however, Hutton (1954) pointed out that much of the survey data also showed positive associations between stocking rate and production per cow, and he questioned the validity of claiming a causal relationship between stocking rate and production per acre. Mitchell (1950) seems to have been one of the first to state clearly that efficiency of per-acre production depended largely on the efficiency of feed utilization and that there were two components of this, namely, the proportion of feed grown which was eaten and the proportion of the feed eaten which. was converted by the animal into salable product. 


\section{EARLY STOCKING RATE AND GRAZING MANAGEMENT TRIALS}

By the mid-1950s the season of conjecture, hypothesis and argument based on survey data was being replaced by a time when experimental results appeared to be clearing up some of the major issues.

Hancock (1953) was one of the first to show that, at quite high stocking rates with dairy cows, production of butterfat per acre could still increase, while production per cow declined. L. R. Wallace (unpublished data) confirmed this situation for dairy cows, and Walker (1955) had similar findings in a stock rate trial with ewes and fat lambs (Table 1).

TABLE 1: STOCKING RATE, PRODUCTION PER ANIMAL AND PRODUCTION PER ACRE

\begin{tabular}{|c|c|c|c|c|c|c|c|}
\hline Typ & 2 of & Stock & $\begin{array}{c}\text { Stocking } \\
\text { Rate } \\
\text { (Animals/ } \\
a c)\end{array}$ & $\begin{array}{l}\text { Prod./ } \\
\text { Animal } \\
(l b)\end{array}$ & $\begin{array}{c}\text { Prod./ } \\
\text { Acre } \\
(l b)\end{array}$ & Aut & thor \\
\hline$\overline{\text { Dairy }}$ & cows & & $\begin{array}{l}1.00 \\
1.66\end{array}$ & $\begin{array}{l}320 \mathrm{BF}^{*} \\
271 \mathrm{BF}\end{array}$ & $\begin{array}{ll}320 & \mathrm{BF} \\
453 & \mathrm{BF}\end{array}$ & Hancock & $(1953)$ \\
\hline Dairy & cows & & $\begin{array}{l}0.84 \\
1.31\end{array}$ & $\begin{array}{c}253 \mathrm{BF} \\
205 \mathrm{BF}\end{array}$ & $\begin{array}{l}213 \mathrm{BF} \\
269 \mathrm{BF}\end{array}$ & Wallace & (unpubl.) \\
\hline Ewes & and & lambs & $\begin{array}{l}4.00 \\
6.00 \\
8.00\end{array}$ & $\begin{array}{ll}34.5 & \mathrm{LC} \\
33.3 & \mathrm{LC} \\
31.6 & \mathrm{LC}\end{array}$ & $\begin{array}{ll}142 & \text { LC } \\
216 & \text { LC } \\
254 & \text { LC }\end{array}$ & Walker & (1955) \\
\hline Ewes & and & lambs & $\begin{array}{l}4.00 \\
6.00 \\
8.00\end{array}$ & $\begin{array}{ll}9.6 & \mathrm{FW} \\
9.2 & \mathrm{FW} \\
8.4 & \mathrm{FW}\end{array}$ & $\begin{array}{ll}43 & \text { FW } \\
61 & \text { FW } \\
80 & \text { FW }\end{array}$ & Walker & (1955) \\
\hline
\end{tabular}

$* \mathrm{BF}=$ Butterfat, LC = Lamb carcass, FW Fleece Wool.

Discussion in New Zealand then shifted to the role which the method of pasture utilization played in animal production. The question at issue was whether stock should be set stocked, or rotationally grazed around a few large or many smaller fields to give the highest return of animal products per acre. The, now classical, experiment of McMeekan (1956) with dairy cows stocked at about 1 cow per acre showed a $13 \%$ difference in butterfat production in favour of a sophisticated rotational grazing system when compared with a set-stocked grazing system. The extra return was believed unlikely to offset the interest on the extra capital cost of fencing and water reticulation involved in rotational grazing.

Other, shorter term trials with sheep and dairy cows substantiated the belief that at the stocking rates being 
employed in the mid-1950s the method of pasture utilization, through manipulation of grazing management, was relatively unimportant in determining production per animal or per acre. This seemed surprising at the time because pasture mowing trials, from the first classical ones of Woodman and Norman (1932), had consistently shown improved pasture production from longer rest periods between mowings, and it was assumed that rotational grazing, rather than set stocking, would provide these longer rests between harvests. And if pasture production was increased, so, it was thought, should animal production.

\section{THE INTERACTIONS OF GRAZING METHOD AND STOCKING KATE}

The only way to evaluate the relative importance of stocking rate and grazing management is by means of factorial-type experiments in which, at a minimum, two stocking rates or two management systems are each examined at two levels of the other factor.

Some of the relevant data from a trial of this sort (McMeekan and Walshe, 1963) are presented in Table 2.

TABLE 2: EFFECT OF STOCKING RATE AND GRAZING MANAGEMENT ON PRODUCTION/ANIMAL AND/ACRE

(2-year average data)

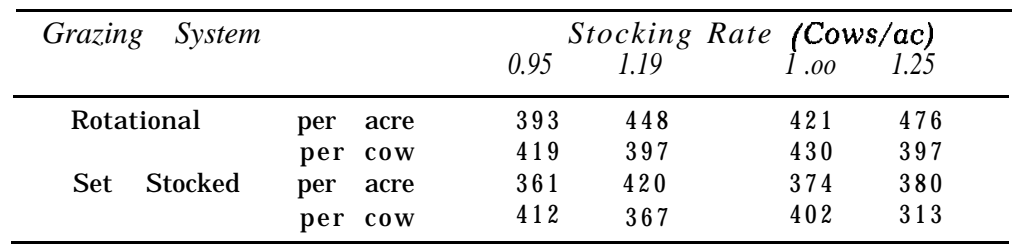

The usual effects of increased stocking rate are seen in lowered per-cow and increased per-acre butterfat production in both two-year periods under rotational grazing, but only in the first period under set-stocked management. Under this management, the higher stocking levels of the second two-year period so depressed per-cow production at the higher stocking rate that per-acre production failed to increase significantly for the first time. The increasing importance of grazing management system as stocking levels are pushed up may be seen more clearly in Table 3 .

Pasture measurements made in the final three years of this experiment (Campbell, 1966) allowed a better understanding of some of the factors involved 'in the animal production outcome, and of hitherto undisclosed weaknesses 
TABLE 3: BUTTERFAT (LB/AC/ANNUM): AVERAGE DIFFERENCES DUE TO STOCKING RATE AND GRAZING MANAGEMENT

\begin{tabular}{|c|c|c|c|}
\hline Year & Stocking Rates & $\begin{array}{c}\text { Difference } \\
\text { Stocking Rate } \\
(H \cdot L) \\
\end{array}$ & $\begin{array}{c}\text { Due To: } \\
\text { Grazing } \\
(R \cdot \text { S.S. }) \\
\end{array}$ \\
\hline $1957-8$ & $\begin{array}{c}0.95 \\
\text { and }\end{array}$ & 59 & 36 \\
\hline $1958-9$ & 1.19 & 55 & 23 \\
\hline $1959-60$ & $\begin{array}{l}1.00 \\
\text { and }\end{array}$ & 29 & 71 \\
\hline $1960-1$ & 1.25 & 31 & 72 \\
\hline
\end{tabular}

in our understanding of grazing dynamics. Pasture dry matter (DM) production was not affected significantly by management or stocking rate. The utilization of pasture by the cows-i.e., the proportion of the DM available which was actually eaten-was affected to almost the same extent by grazing management as it was by stocking rate. The percentage of pasture utilization at a single fortnightly grazing was unexpectedly low. It averaged only $25 \%$ for all treatments and years. But this percentage of singlegrazing utilization was very positively correlated with butterfat production per acre, under these conditions in which pasture production did not differ greatly between treatments.

A further interaction was uncovered which opened the way to improvement of grazing management systems. Raising stocking rate under set-stocked management raised the single-grazing percentage utilization of pasture by only a proportional amount, but under rotational grazing the increase in utilization was much more than proportional to the stocking rate increase. This effect appeared to be related to the differential between the grazing systems in the area closed for silage and hay, this area being greater on the rotationally grazed system.

Pasture utilization then could be raised in three ways: by increasing stocking rate, by increasing the area conserved and feeding the silage or hay back in winter, or by some combination of these two. Data on available DM and cow liveweight, obtained simultaneously, suggested that the cows being rotationally grazed at the high stocking rate were probably being underfed in spring because so much of their area was closed for conservation. This led us to recognize the need for better definition $o_{i}{ }^{\prime}$ minimum winter feed requirements of silage and hay, so that the "conservation pinch" might be avoided if possible. A management 
experiment at Ruakura (P. W. Young, unpublished) showed that, at a high stocking rate (1.66 cows/ac) animals less well fed in winter because less conserved fodder was made for them, so that they did not suffer the "conservation pinch", outproduced, by $12 \frac{1}{2} \%$, their identical twin mates well fed in winter but slightly underfed in spring and summer because of their conservation needs. The less well wintered group were also $35 \mathrm{lb}$ heavier at drying off, because of better summer feeding.

At the same time, in the course of a winter feeding trial, No. 2 Dairy, Ruakura, carried 1.75 cows per acre at lower levels of conservation and winter feeding than had previously been used. Production from entirely grass-fed cows was lifted to over $600 \mathrm{lb}$ butterfat per acre compared with the previous maximum for this dairy of $500 \mathrm{lb}$ (Campbell and Clayton, 1966).

It is now accepted, so far as dairying is concerned, that grazing management has an essential part to play at high stocking rates. This part lies in permitting the correct redistribution of available feed between dry and lactating stock, between physiologically responsive stock and less responsive ones, and between seasons of surplus and deficient grass supply. What precisely this correct redistribution is remains imperfectly understood, but it is now easier to understand why, at lower stocking rates, at which feed is more or less abundant at all seasons for all classes of stock, grazing management becomes of much less importance.

In an attempt to improve pasture utilization even further, other workers have stocked milking cows at two per acre, frankly above the carrying capacity of the pasture, and fed grain supplements to "top up" the feed supply in periods of pasture deficiency (Hutton, 1968). This has lifted butterfat production per acre to over $700 \mathrm{lb}$ in one season, although a proportion of this is attributable to the grain supplement. The economics of this system will depend on the value of butterfat relative to the cost and amount of the supplements which must be fed, and these may both vary from year to year.

\section{PASTURE PRODUCTION AND MANAGEMENT UNDER} INTENSIVE UTILIZATION

Earlier, reference was made to the work of Woodman and Norman (1932) which showed marked pasture yield benefits from longer "spells" between successive mowings. Pasture measurement under actual grazing is fraught with 
problems and Campbell (1966) was unable to show any statistically significant difference in pasture yield between set-stocked grazing and a 14-day rotational system at 1 and 1.2 cows per acre. Both Smith (1964) and Campbell (loc. cit.) have shown small, but insignificant, depressions in pasture yield under heavier stocking in the range of 1 to 1.5 cows per acre. This has been an encouraging finding as intensity of utilization has progressively increased, but the inability to show any benefit in pasture yield from rotational grazing has been confusing. Recently, however, Campbell (1969) using stocking rates of 10 and 15 ewes plus lambs per acre on 7 - and 28-day rotations has been able to demonstrate a significant depression of pasture production on the 7-day rotation when stocking rate was raised from 10 to 15 ewes per acre. A $50 \%$ increase in pasture yield at 15 ewes per acre under the 28-day rotation compared with the 7-day was also demonstrated. The effect upon the pasture of such a high stocking rate with sheep is clearly rather similar to the use of a mowing machine, and it seems possible that the Woodman-type yield response to different forms of management is only likely to be achieved when stocking rate is so high that the grazing animal simulates the lawnmower. Campbell (1969) postulates that Watson's (1956) Leaf Area Duration concept is the important physiological determinant of yield in such a situation;

If this large pasture yield response to management under very intensive utilization can be accepted and, preferably, confirmed by further work, it would seem to provide yet another challenge in the attempt to achieve even higher animal production through complete utilization of the additional pasture grown under slow rotational grazing.

\section{ECONOMIC ANIMAL PRODUCTION}

In pursuit - of improved pasture utilization, the New Zealand researcher has tended to reard maximum animal production per acre as an end in itself. The purpose would better be to show farmers how to obtain maximum per-acre income. That there I-nay be a conflict here is evident from the work of Joyce et al. (1969) (Table 4). A farmer inay be doing himself a disservice by pursuing maximum animal production, especially if his farm ceases to be self-contained and fodder has to be purchased. His search for maximum economic returns may be met more easily by changing his type of farming. 
INTENSIVE PASTURE UTILIZATION

TABLE 4: STOCKING RATE, PRODUCTION/ACRE AND GROSS MARGIN/ACRE

\begin{tabular}{ccc|cccc}
\hline $\begin{array}{c}\text { No } \\
\text { Cattle/ } \\
\text { ac }\end{array}$ & $\begin{array}{c}\text { Net } \\
\text { Carcass } \\
\text { Meat/ac } \\
(\text { lb) }\end{array}$ & $\begin{array}{c}\text { Gross } \\
\text { Maginiac } \\
(\$)\end{array}$ & $\begin{array}{c}\text { No. } \\
\text { Breeding } \\
\text { Ewes/ } \\
\text { ac }\end{array}$ & $\begin{array}{c}\text { Lamb } \\
\text { Meat/ } \\
\text { ac } \\
(l b)\end{array}$ & $\begin{array}{c}\text { W ool/ } \\
\text { ac }\end{array}$ & $\begin{array}{c}\text { Gross } \\
\text { Margin/ } \\
\text { ac } \\
(\$)\end{array}$ \\
\hline $1 \frac{1}{2}$ & 556 & 82 & 8 & 245 & 71 & 51 \\
23 & 630 & 71 & 10 & 308 & 86 & 55 \\
23 & 699 & 75 & 12 & 334 & 100 & 52 \\
\hline
\end{tabular}

The research worker must not lose sight of the underlying economic motive for his work and should try whenever possible to evaluate the costs involved in maximizing production, not only the returns.

\section{REFERENCES}

Campbell, A. G., 1966: J. agric. Sci., Camb., 67: 199.

1969: N.Z. Jl agric. Res., 12: 67.

Campbell, A. G.; Clayton, D. G., 1966: Proc. Ruakura Fmrs' Conf. Week: 181

Dick, I. D., 1950: N.Z. Jl Sci. Technol., 31B (6): 1.

Fawcett, E. J., 1929: Dairy farm management. N.Z. Dept. Agric. Bull. 138: $68 \mathrm{pp}$.

Hancock, J., 1953: N.Z. Jl Sci. Technol., 35A (2): 67.

Hutton, J. B., 1954: Dairy farm survey of the Waipa County, 1940-41

to 1949-50, N.Z. Dep. Sci. industr. Res. Bull, 112, 79 pp.

- 1968: Proc. Ruakura Frms' Conf. Week: 215.

Joyce, J. P.; Rattray, P. V.; Oliver, T. W., 1969: Proc. Ruakura Fmrs' Conf. Week: 85.

McMeekan, C. P., 1956: Proc. 7th int. Grass/d Congr.: 146.

McMeekan, C. P.; Walshe, M. J., 1963: J. agric. Sci., Camb., 61: 147

Mitchell, K. J., 1950: N.Z. Jl Sci. Technol., 3lA (6): 64.

N.Z. Official Yearbook, 1938: Govt. Printer, Wellington.

Smith, B. A. J., 1964: Proc. Ruakura Fmrs' Conf. Week: 204.

Walker, D. E., 1955: Proc. N.Z. Soc. Anim. Prod., 15: 51.

Wallace, L.R., 1956: Unpublished; quoted by McMeekan (1956).

Watson, D. J., 1956: Proc 3rd Easter School agric. Sci. Nottingham Univ.: 187

Woodman, H. E.; Norman, D. B., 1932: J. agric. Sci., Camb., 22: 852.

\section{DISCUSSION}

Brougham commented that, in view of the NDC recommendations which called for increased production, it appeared there might be a conflict between national and farmer interests in some situations, particularly where gross margins tended to fall at some very high stocking rates. Campbell thought there was no answer to this conflict, outside of a political one. To a query from Mitchell as to why gross margins had fallen, Campbell replied that it was largely because the systems had not been completely self-contained and some supple- 
mentary fodder had to be bought in. Woodford (U.K.) observed that in a grazing system there was always some fouling of the pasture with dung and urine. He wondered how important this fouling was in the grazing systems described in terms of feed acceptance by the animal. Campbell felt that it was not very important since the animal had little choice as the stocking rates increased. Browne (Ireland) asked what percentage of the passture was utilized and Campbell replied that it was difficult to achieve better than $40 \%$ at a single grazing.

The animals were in a paddock for only one day and pasture measuud yas available dry matter. Asked if utilization was the same with sheep as with cows, he said it depended on how they were equated. It would be similar if the ratio was seven sheep to one cow. Heath (U.S.A.) inquired whether emphasis would be on the Friesian for beef production in the future, to which Campbell replied that there was a fair tendency in that direction. Ten years ago, $80 \%$ of the cows in the A.B. scheme were Jerseys, while today Friesians had risen to $38 \%$. Asked by Langer what the ultimate stocking rate for dairy cows, without supplements, would be, Campbell stated that that depended on many factors such as soil fertility and topography, At Ruakura they had carried 1.75 , but he considered 1.66 would be nearer the limit on those and similar soils. O'Connor asked if Campbell could suggest the most serious problems resulting from low percentage utilization at each grazing. Campbell said in reply that dry matter not. utilized at one grazing would be carried forward. After 6 to 8 weeks, that not utilized would decay and die and be lost to the system. It was most important to use as high a proportion as possible to avoid such losses which more lax grazing systems tended to promote. 